\title{
A new NATO
}

The Great role of conduct for us, in regard to foreign nations, is in extending our commercial relations to have with them as little political connection as possible. ... Europe has a set of primary interests, which to us have none, or a very remote relation. Hence she must be engaged in frequent controversies, the causes of which are essentially foreign to our concerns ... 'Tis our true policy to steer clear of permanent Alliances, with any portion of the foreign world. (George Washington) ${ }^{1}$

\section{Summary}

The disappearance of the Soviet Union and the end of its hold over Central and Eastern Europe posed the question of the future of NATO. What continued purpose could NATO serve? How far east could it enlarge without upsetting Russia? NATO's first enlargement in 1999 included the Czech Republic, Hungary and Poland, while various cooperative programmes with other countries in the region, including Russia and Ukraine, were expanded.

NATO's first ever armed conflict was with Yugoslavia in the spring of I999 over the latter's Kosovo province and over Serbian mistreatment of ethnic Kosovo Albanians. After three months of aerial attacks, NATO stood victorious and a major international troop presence restored relative calm to the province.

The Kosovo War led to intensified discussion in Europe and the United States over the need for increased European defence spending and operational efficiency within the alliance and over the prospects of more 'outof-area' peacekeeping or peacemaking operations, such as in the 'former Yugoslav Republic of Macedonia' in 200I. European efforts to achieve greater defence autonomy (see also Chapter 9) met with initial scepticism by the United States. The Europeans showed similar scepticism as regards preliminary US plans for a Strategic Missile Defence project aimed at developing the capacity for shooting down incoming missiles.

The terrorist attacks against the United States on I I September 200 I and the converging interests of the United States and Russia by mid-2002 
modified the situation. Both sides abrogated the I972 Anti-Ballistic Missile Treaty, thus permitting the US anti-missile project to go forward. The two countries also concluded the Treaty of Moscow, signifying deep cuts in their strategic nuclear arsenals. Russia's relations with NATO became even closer with the creation of a NATO-Russia Council. At a summit in Prague in November 2002, NATO undertook its second enlargement in the post-Cold War era, as it invited Bulgaria, Estonia, Latvia, Lithuania, Romania, Slovakia and Slovenia to join in 2004.

However, questions regarding NATO's continued relevance arose anew, as the US showed an increasing propensity to act independently of the organisation, as the Europeans lagged behind in defence spending and technology and as differences in the willingness to use military might began to appear, such as in the Iraq crisis in 2003, which exposed deep rifts in the perception of outside threats and the action to be taken in their regard. NATO was not likely to disappear as it was still useful to both sides, but the communality of purpose was not the same as it had been during the Cold War.

\section{NATO in the 1990s: where is the enemy?}

When Mikhail Gorbachev began to apply his 'new thinking' to foreign policy in the late I980s, Georgi Arbatov, his expert on North America, jokingly issued this threat to a NATO official: 'We will do something terrible to you - deprive you of your enemy'. This threat came true when the Warsaw Pact was dissolved in the summer of I99I and the Soviet Union ceased to exist in November of that year.

A military alliance without an enemy has every difficulty of surviving. NATO would have to find a new enemy, or at least a mission equivalent thereof, and with it a new role. A first effort was made in I99I, with the announcement of a new Strategic Concept. The enemy found was 'instability'; the method was inclusion or enlargement; and the role was a shift from major war-preparedness to, primarily, crisis management, peacemaking, peacekeeping and other 'soft' uses of military might.

The successive decisions leading up to this new posture started with a number of questions. First, after the break-up of the Soviet Union and the dissolution of the Warsaw Pact, should there remain, on the landscape of Europe, a military alliance, or should NATO dissolve? The official answer by the NATO countries to this first question was that an alliance was still needed, because their security might continue to come under threat. Such contingencies could arise from regional conflicts or instability due to ethnic and other tension inside one country or between 
countries; or they could be external, from the south or from the east, especially in an era of modern missile technology, weapons of mass destruction and terrorism. ${ }^{2}$

Second, should a new alliance take the place of NATO? NATO members, and in particular the United States, concluded that it would be easier and cheaper to build on something already existing rather than start from scratch. Furthermore, NATO had come to be seen as the symbol of North American commitment to the defence of Europe. ${ }^{3}$ Finally, NATO had proved its ability over the years to assist in peaceful integration and democratic development of the continent - such as in helping the defeated powers of Italy and Germany to join it; in the European construction efforts since the I950s; in spurring reconciliation between France and Germany; in keeping peace, however fragile, between Greece and Turkey; and in providing a unified military command, thereby creating transparency and trust among the member states and removing the incentive for military competition among West European powers.

A third question to be answered was whether a continued NATO should enlarge or not. In the end the 'yes' prevailed. Part of NATO's post-Cold War mission had become to promote an evolution in the countries of Central and Eastern Europe towards civil society, a market economy and peace with their neighbours. It was felt that NATO membership for the countries concerned would benefit this process. Conversely, a decision not to expand would risk being seen by these countries as a parallel to the decision of the United States not to join the League of Nations after World War I; as relegating them to a permanent 'buffer zone' between East and West; and as a punishment for having involuntarily been conscripted to the Warsaw Pact during the Cold War. Both internal and external instability might have followed. As the leaders of the sixteen NATO member states gathered in Madrid in July I997, the question was therefore not whether, but how far, the alliance should enlarge.

\section{Three new NATO members in 1999}

At US (and British) insistence, invitations were initially limited to the Czech Republic, Hungary and Poland, with most European NATO members (and especially France and Italy) advocating early membership also for Romania and Slovenia (they were singled out in the final communique as being next in line for 'preferential consideration'). Negotiations with the Czech Republic, Hungary and Poland were finalised by the end of I997 and NATO's third enlargement was celebrated at a 
summit in Washington in April I999, the fiftieth anniversary of the Washington Treaty (at which time the alliance might statutorily have been dissolved).

The decision to undertake a 'mini-enlargement' of this kind capped a longstanding effort on the part of the three successful candidates - the Czech Republic, Hungary and Poland - for full economic and political integration into what could still, though somewhat archaically, be called 'the West': a Euro-Atlantic community of shared values and goals, while holding out the same prospect for their neighbours in the region. Neither the Council of Europe nor the OSCE had been able alone to satisfy this aim.

The Washington Summit also decided to build a European Security and Defence Identity within the alliance. The policy called for a much stronger European responsibility in handling future conflicts of the Kosovo type. New threats would be brought to NATO's attention, giving it a right of 'first refusal'. In cases where the alliance would not want to act as such, a European Union chain of command would be expected to take over responsibility, borrowing equipment from NATO (and especially the United States). Such material could include spy satellites, cargo planes and position-guided cruise missiles.

Russia had not expressed any wish to join NATO. Instead, a NATORussia Founding Act on Mutual Relations, Co-operation and Security (falling short of treaty value) had been signed in Paris in May I997, establishing a Russian diplomatic representation at NATO headquarters in Brussels and concrete procedures for consultation and co-operation between NATO and Russia. They included a Permanent Joint Council meant to soothe Russian apprehension about the alliance's eastward enlargement and to step up co-operation on peacekeeping (such as in Bosnia and Kosovo), anti-terrorism and ways to curb the spread of weapons of mass destruction. ${ }^{4}$

In addition, Russia was invited to join numerous other non-NATO members - and all NATO countries - in a new, at the time, forty-threemember Euro-Atlantic Partnership Council (EAPC) with basically the same purpose. ${ }^{5}$ A similar agreement - a Charter of a Distinctive Partnership (again no treaty value) - was concluded in Madrid in 1997 between NATO and Ukraine, providing for the two sides to develop a crisis mechanism to consult together whenever Ukraine perceived a 'direct threat to its territorial integrity, political independence or security'. ${ }^{6}$

The emphasis in these agreements was on contacts, co-operation, sharing and rules of conduct. They had in common that they wanted to include, not exclude - perhaps even to a fault in that it might become 
difficult for a continuously enlarged NATO to live up to its collective defence commitments. ${ }^{7}$

\section{The war over Kosovo}

In the night of the 23 March I999, almost to the day fifty years after its creation, NATO fired its first shot in anger, as aircraft took off from bases around Europe and the US to bomb Yugoslavia. Thus ended fifty years in which the alliance had not had to act, and therefore had successfully realised its mission.

The main reason for the attack, named 'Allied Force', was the way Yugoslavia, under its President, Slobodan Milosevic, had been treating the ethnic Albanian majority in its southern-most province of Kosovo. Killings of civilians, executions of able-bodied men and 'ethnic cleansing' of entire towns and villages was leading to thousands of refugees leaving Kosovo for shelter in the neighbouring 'former Yugoslav Republic of Macedonia', Albania and Montenegro (the second state in the Yugoslav federation). Such atrocities were happening in many other places in the world. However, this was Europe, NATO's doorstep. NATO was driven into action after it had delivered a long series of threats and ultimatums which, when not met, called into question NATO's very credibility.

The conflict was to last much longer than anyone had expected, until June 1999 when Yugoslavia accepted the conditions for a ceasefire belatedly agreed among the members of the United Nations' Security Council. ${ }^{8}$ On NATO's side the war was waged entirely from the air to avoid the delays, cost and potential casualties among troops and civilians associated with a land-based invasion of Kosovo (or even Yugoslavia) a process during which NATO's fragile inner cohesion could easily have frayed.

This, however, inadvertently became an excuse for Serb militias and even regular Yugoslav troops to accelerate their 'ethnic cleansing', driving additional thousands of ethnic Kosovo Albanians into especially the 'former Yugoslav republic of Macedonia'. It also bolstered a feeling of martyrdom among the Yugoslavs and strengthened their patriotism, especially after NATO began bombing major bridges and other infrastructure in Serbia. The Serb leadership for its part underestimated NATO resolve in continuing with the air strikes and the ability of its members, including those least enthusiastic about the war, to stick to the battle plan. Serbian leaders also overestimated Russia's willingness, or ability, to support them, while in the end that country's role as mediator became essential to putting a stop to hostilities. 
In the war's aftermath, as peace returned to Kosovo and along with it thousands of ethnic Albanian refugees, there was awe of NATO's military prowess, and especially that of the United States. However, there was also criticism, especially as the Kosovo Albanian side was becoming increasingly aggressive vis-à-vis the remaining Serbs and other ethnic groups. Furthermore, questions were asked whether the negotiations conducted with Yugoslavia in February I999 to reach an agreement over Kosovo had been more than a series of ultimata that had been exceedingly difficult for the Yugoslav leadership to accept, such as the one demanding right of access of NATO troops to any part of Yugoslavia. ${ }^{9}$

Europe after Kosovo was in many ways different from what it had been before the conflict. In launching the war, NATO's nineteen members - all democracies - were aware that they were abandoning a basic principle in international law, forbidding an attack against a country that had not violated international borders (unless, since the establishment of the UN, mandated to do so by its Security Council). It was clear to all that the Federal Republic of Yugoslavia had not violated any international border, nor had it threatened to in this case (even though it had done so a few years earlier, in its wars against the then newly established Croatia and Bosnia-Herzegovina).

If the NATO action over Kosovo did not conform strictly to established international law, it nevertheless reflected the moral outrage felt by the international community at the forced expulsion of a whole people and the systematic murdering of thousands. Milosevic's actions flew in the face of the efforts of half a century of the United Nations, the Council of Europe, the European Union and NATO to reconcile nations, peoples, and promote human rights and tolerance. ${ }^{\text {IO }}$ NATO's action was in line with a more recent trend in history in the direction of greater international intervention on behalf of humanitarian values, as witnessed for instance in the creation of an International Criminal Tribunal for the former Yugoslavia in The Hague a few years earlier. ${ }^{\text {II }}$

This new component in international law had been in gestation over the previous decade and had found expression in various OSCE and Council of Europe summits, even though it has not been enshrined formally as has, for example, the sanctity of borders. The world is still grappling with the terms by which the international community may intrude on national sovereignty to redress genocide or other atrocious crimes perpetrated by governments against their own populations. ${ }^{\mathrm{I2}}$ 


\section{NATO and Russia in the 1990s: how far should enlargement go?}

Many people in the early I990s were opposed to any NATO enlargement, along the lines of 'If it ain't broke, don't fix it'. Among them was the ageing George Kennan, the great scholar of Russian affairs, who in I946 had first warned about Soviet intentions vis-à-vis the West. Kennan maintained that enlargement could 'inflame nationalistic, anti-Western and militaristic tendencies in Russian opinion'. To such commentators, I989 marked a break in European history, in that it ended a comparatively stable balance-of-power era. NATO and the Warsaw Pact had stood against each other during the Cold War, ensuring an uneasy and at times tense balance. 'Armed transparency' had been achieved thanks to new technologies of verification, leading to arms-control measures, détente and eventually the peaceful collapse of one side. Since 1989, it was argued, there had not been any balance, but rather economic and political co-operation and integration. Why, then, now enlarge NATO and thereby risk unbalancing and remilitarising a relationship between Russia and the West, which since 1989 had been relatively stable?

Russia, critics maintained, was likely to view such an expansion as an extension of US hegemony in Europe - with NATO as the instrument of US predominance not only in Western Europe but also in its Central and Eastern parts. It would, it was argued, weaken the 'Atlanticists' in the Russian political establishment and give new wind to militaristic and nationalist circles - in the process jeopardising Russia's ratification of the US-Russia START II Treaty reducing nuclear missiles and the beginning of negotiations for the even further-reaching START III. Why, those against NATO enlargement continued, humiliate Russia when it was on its knees - its army in tatters, facing a resurgent China to its southeast and a score of Islamic and potentially hostile central Asian countries to its south?

Those in favour of enlargement, however, argued that Russia was not in a position to halt the enlargement process to any significant degree, due to its economic and military weakness. When it became stronger on all these fronts again, as inevitably it would in time, it might well find that there was nothing to fear from neighbouring NATO countries, whose foreign policy ambitions could perhaps better be held in check by NATO membership and the common desire for European peace and a stable and prosperous Russia. Russian relations with NATO and the West in general would, they felt, to a large extent depend on whether the country could be successfully integrated economically with the rest of Europe and the world. Economic integration with the West, coupled 
with co-operation with NATO, could provide stability on Russia's western flank and prevent a remilitarisation of its economy. ${ }^{\mathrm{I3}}$

Slovenia, Romania and possibly Bulgaria seemed likely new entrants in the early years of the new century. Slovenia was in many ways the most likely candidate in such a 'second wave', as it could easily finance its membership and had never been a member of the Warsaw Pact. In addition, it would give NATO a presence (beyond Greece and Turkey) in South-Eastern Europe and thus help stabilise that volatile region. ${ }^{\text {I4 }}$

The Baltic States - Estonia, Latvia and Lithuania - fervently aspired to NATO membership. The question remained whether NATO members would risk taking a step that in Moscow might be seen as a provocation, if not a threat. The Charter of Partnership signed between the United States and the three Baltic presidents in Washington in I998 was not a treaty. But it put on record the 'real, profound and enduring interest' of the US in the independence and security of the three countries and a US commitment to support their aspirations to join NATO.

Soon the opinion in NATO capitals swung in favour of wider and earlier enlargement. Sensing this, nine Central and East European countries - Lithuania, Latvia, Estonia, Bulgaria, Romania, Slovenia, Slovakia, Albania and the 'former Yugoslav Republic of Macedonia' - in May 2000 pledged to work together for a 'big bang' solution to early NATO membership involving them all. ${ }^{15}$

A year later, in Warsaw in June 200I, President George W. Bush in a speech boldly stated:

All of Europe's democracies from the Baltic to the Black Sea, all that lie between, should have the same chance for security and freedom - and the same chance to join the institutions of Europe - as Europe's old democracies ... I believe in NATO membership for all of Europe's democracies that seek it and are ready to share the responsibilities that NATO brings ... As we plan to enlarge NATO, no nation should be used as a pawn in the agendas of others. We will not trade away the fate of free European peoples. No more Munichs. No more Yaltas. ${ }^{16}$

This statement was an indication that the US, too, was now prepared for a radical NATO enlargement. The US Congress would find it difficult to refuse to go along, given the large 'ethnic vote' in the US with roots in the different candidate countries involved. 


\section{A NATO transformed: the 2002 US-Russia Treaty of Moscow and the NATO-Russia Council}

In May 200I US President George W. Bush announced his administration's determination to build a Ballistic Missile Defence (BMD), a broad array of defences to protect against missiles launched by so called 'rogue states' or 'states of concern'. ${ }^{17}$ The project, which had been contemplated also by the preceding Clinton administration, was received with caution in European NATO capitals, suspicion in Moscow and hostility in Beijing.

One complication was that, if installed, the BMD would violate the I972 Anti-Ballistic Missile (ABM) Treaty between the United States and the Soviet Union, which forbade anything more than minimal missile defences for either side. ${ }^{\mathrm{I}}$ West European concerns were that the BMD would be seen by the rest of the world, and especially by Russia and China, as confrontational and menacing rather than co-operative and that it would have destabilising consequences for the international nuclear arms balance.

However, criticism was subdued for several reasons. Firstly, it could prove politically costly to protest too strongly against the right of the American people to defend itself, especially as it seemed to stand so solidly behind the project. Secondly, it was difficult to argue against a defensive as opposed to an offensive system, not least since the Europeans, including the Russians, might some day benefit from it in defending against rogue attacks - Western Europe, say, from the Middle East, or Russia from its south and south-east. Thirdly, the European NATO allies and Russia could benefit from being included in a system that neither would be able to afford on their own. Finally, NATO-Europe might also in exchange receive a more positive US attitude to the European security and defence policy and the latter's Rapid Reaction Force. ${ }^{19}$

By June 2002 both the Ballistic Missile Defence issue and that of the ABM Treaty appeared to have been solved. President Bush abrogated the ABM Treaty, arguing that the terrorist attacks against the United States on I I September 200I had clearly demonstrated that the Cold War was over and that BMD was urgently needed. Russia followed suit the following day and at the same time announced that it no longer felt bound by the START II Agreement that had outlawed multiple-warhead missiles and other especially destabilising weapons in the two countries' strategic arsenals. ${ }^{20}$

Both sides' abandonment of the ABM Treaty and Russia's leaving START II would have sent shock waves through the world only a few years earlier. As it happened, however, they were preceded by a series of agreements that rendered them relatively benign. In May 2002 Presidents 
Bush and Putin signed the Treaty of Moscow, which committed the US and Russia to reducing their nuclear arsenals from about 6,000 warheads each to no more than 2,200 by $2012 .{ }^{21}$ Talks would also start on the difficult issues of better transparency and verification as regards nuclear warheads, whether in use or scrapped.

A few days later, a NATO summit in Rome established a NATORussia Council, which in essence brought Russia inside the alliance by giving it an 'equal partnership' role on issues such as counter-terrorism, peacekeeping interventions and the spread of nuclear weapons, though not on core military issues such as those relating to collective defence or out-of-area peacemaking operations. ${ }^{22}$

The NATO-Russia Council held several advantages to all sides. It reduced Russian apprehensions about any future NATO enlargements and indeed stimulated co-operation between Russia and the European Union, as well as with future NATO members it had once dominated. It ensured Russian support for NATO's and the West's fight against terrorism and helped diffuse the criticism in Russia that the country had received little in return for its support of the West in that struggle since the terrorist attacks against the United States on I I September 200I. It also bound NATO closer to Russia in the protection of its interests vis-àvis its southern neighbours in central Asia. ${ }^{23}$ Furthermore, the NATORussia Council aligned NATO to a new European reality, which transcended the former Cold War divide between East and West, as symbolised by the forthcoming enlargement of the European Union. The United States (and Canada) could thereby retain a formal role in fostering security in that more integrated Europe.

On the other hand, the agreement by the same token diluted NATO's role in the eyes of those NATO candidate countries which had viewed NATO membership as a bulwark against any future Russian attempt to dominate them. There was also the general European apprehension that, as during the Cold War, Moscow and Washington would now settle the big issues among them, indeed worsening a situation where Washington seemed only to be using NATO when it pleased it, such as in building a coalition (as it happened, outside NATO) for the war in Afghanistan following I I September.

\section{The 2002 NATO summit in Prague: seven new members}

The NATO summit in Prague in November 2002 brought the answer to the growing sentiment in favour of NATO enlargement. At the summit, the organisation undertook its second enlargement in the post-Cold War 
era by permitting seven new countries to join, thereby bringing the membership to twenty-six. The seven new members were Bulgaria, Estonia, Latvia, Lithuania, Romania, Slovakia and Slovenia.

The speeches at the summit referred to the final closure of the legacy bequeathed by the 1939 Hitler-Stalin Pact, Yalta and Potsdam. Luxembourg Prime Minister Juncker exclaimed: 'Our grandfathers and fathers could not have imagined what has become reality today!', while departing Czech President Vaclav Havel, himself a former political prisoner under the communist regime, described the event as the end of European power politics and of the imposition of the stronger's will on the weaker. There was something truly remarkable in the fact that not only several countries in the former Warsaw Pact had joined, but also those Baltic states which only a decade before had formed part of the Soviet Union and this with barely an eyebrow raised in Moscow. ${ }^{24}$

The Prague Summit also resolved to adapt the alliance to the new security needs that had arisen as a result of terrorism and the spread of weapons of mass destruction. It was decided to establish a 20,000strong NATO Response Force (NRF), which would be fully operational by 2006 and consist of highly mobile elite forces capable of intervening also in faraway places. The Response Force was politically anchored in a so-called Prague Capabilities Commitment, by which the member states vowed to remedy shortcomings in areas such as air transport, munitions and protection against atomic, biological and chemical weapons.

To certain less Atlanticist EU members, such as France, the NATO Response Force might not have been an entirely welcome development, since it would have to draw on limited resources in competition with the EU's own emerging Rapid Reaction Force. They may have seen US pressure for the NATO force as a deliberate means to make the EU force toothless. If so, the new NATO members could be expected to come to the support of the US, as they were on the whole more Atlanticist than some West European EU members.

Using Central European forces for the NATO Response Force would also be convenient, considering the clear US wish to see NATO's future as lying primarily to its east and south-east, that is, in central Asia and east of Turkey. This also helped to explain US pressure for early Turkish membership in the EU. Both NATO and the EU would then be in a position to project their influence on to the Caspian Sea region and even to its east. (Georgia and Azerbaijan had both announced an interest in joining NATO.) The aim would be to be in a better position to fight terrorism, open new oil and gas fields in the Caspian Sea region and secure the transport of these resources to Europe and the world. 
For the European Union, the question became one of deciding on how far it wished to follow the US on this course and, if it chose not to, whether it could muster the political will to part ways with NATO. Given the imminent enlargement of both NATO and the EU to include more Atlanticist countries in the east and south-east - to which should be added traditional Atlanticist members such as the United Kingdom and the Netherlands - the likelihood of that happening was limited.

\section{NATO's future mission and relevance}

Even before the Prague Summit, questions had arisen as to NATO's future mission, and indeed relevance. ${ }^{25}$ It was clear that NATO would be needed in the fight against terrorism and out-of-area interventions such as in the Balkans. Furthermore, as the European Union's efforts to mount a Rapid Reaction Force independent of NATO showed signs of fatigue, the Europeans (and especially the countries of Central and Eastern Europe) seemed to acknowledge that they would not be able to defend the continent without NATO.

Aside from its new tasks, NATO will inevitably change its character simply by being enlarged. Peacemaking or peacekeeping inside or among member states and out-of-area operations, for instance to rescue civilians in countries south or east of the Mediterranean, are likely to become NATO's operational mainstay, rather than the massive mobilisation of forces for defence of NATO territory that so dominated past thinking. Furthermore, NATO intervention - or NATO-approved intervention by the US or one or more European NATO members - undertaken without the sanction of the UN Security Council may become more frequent, as the Kosovo conflict demonstrated.

NATO is developing a 'southern strategy' for NATO to supplement its historical 'northern' one in Central Europe. It is based, not on territory, but on common interests, to the extent these can be found. It includes countering terrorist states that brandish weapons of mass destruction, preventing conflict in the Balkans, undertaking rescue operations of civilians in faraway places, and maintaining access to Gulf oil.

The 'southern strategy', while potentially embraced by all, would probably see ad hoc 'coalitions of the willing', with membership depending on the particular threat posed. Thus Mediterranean NATO countries may co-operate in rescue operations in North Africa. The strategy would have to gain the support both of NATO's northern European members, naturally more concerned about the 'northern strategy', and its Southern European members, more worried about NATO's southern and south-eastern vicinity. 
Already, additional emphases are coming to the fore, reflecting the fear on both sides of the Atlantic of a menacing triad of 'rogue states', weapons of mass destruction (WMD) used without or with little warning, and terrorists. In brief, unless prevented from doing so, 'rogue states' such as North Korea would be in a position to produce WMDs and sell them to terrorists, who could transport them to, say, New York harbour, Washington DC or central London. This would be the ultimate nightmare from the defence point of view, since deterrence would have failed and retaliation would be made difficult or impossible for want of an identifiable aggressor country.

The resulting change in US defence doctrine consists in adding 'prevention' or even 'pre-emptive prevention' to 'deterrence', since 'deterrence' - in a departure from what was the case during the US-Soviet stand-off during the Cold War - cannot be counted on to work against a suicidal rogue-state ruler, and even less against terrorists. ${ }^{26}$

Related to the above is a growing concern over a breakdown of countries as such and the resulting greater ease for terrorists to operate in them, such as has occurred or is still the case in countries like Somalia, Afghanistan and the Sudan. State breakdowns would force the established powers to engage in additional preventive action and thus further erode the tenet of border inviolability in classical international law. The preservation of states and their ability to control terrorism within their borders can therefore be expected increasingly to form part of the security policy of the established powers.

A new National Security Strategy of the United States, presented in 2002, makes this clear. Quoting from a speech by President Bush in 200I, it states that:

We must be prepared to stop the rogue states and their terrorist clients before they are able to threaten or use weapons of mass destruction against the United States and our allies and friends. Our response must take full advantage of strengthened alliances and the establishment of new partnerships with former adversaries, innovation in the use of military forces, modern technologies, including the development of an effective missile defence system and increased emphasis on intelligence collection and analysis. ${ }^{27}$

If NATO's European members truly desire to maintain the organisation's relevance for, and support from, its strongest member, the US, they will have to contribute to this strategy plan also for the protection of Europe itself, since the effective threat against Europe from terrorists and weapons of mass destruction is as great or perhaps even greater than that against the United States. ${ }^{28}$ 


\section{The US attitude to NATO: still the priority?}

Another question became how the Americans felt about the organisation and how well it fitted in with their own perceptions of the world and interests. NATO had enjoyed a revival of sorts in the I990s and early 2000 in Bosnia, Kosovo and the 'former Yugoslav Republic of Macedonia'. The overriding question was whether another one could be expected in the future without a fundamental scrutiny of what the organisation should stand for.

The United States had waged its war in Afghanistan outside the NATO framework, merely calling on one or the other NATO ally to perform ad hoc tasks, whether in the United States to protect the skies against new acts of air terrorism or in assisting in clean-up operations in Afghanistan. It could even be expected that in many and perhaps most cases, the United States would take recourse to 'coalitions of the NATO-willing', as in Iraq in 2003 , in order to avoid the 'warfare-by-committee', Kosovostyle intervention. NATO as such would then be used for political support, and as a 'toolbox' for identifying the 'willing' and the 'able' and especially those both willing and able - and for post-military peacekeeping. Waging war alone would also present fewer problems related to the widening technological gap between the US and its allies, a factor that had made joint operations increasingly difficult.

Beyond such considerations, there were the different views of the world held by either side. The Europeans had reason to believe that they had moved their continent to a rules-based unity and harmony via decades of negotiation and co-operation and the renouncement of force. Surely the world could be brought to the same happy state via international treaties such as the International Criminal Court, which would bring miscreants such as any new Pol Pot or Milosevic to justice.

If that was Europe's new mission civilisatrice, the US by contrast saw the world as a much more anarchic place, where strength and power still mattered, where recourse still occasionally had to be taken to unilateral action, such as in Afghanistan against Al Qaida, or against the 'axis of evil' - to use President George W. Bush's expression - of Iraq, Iran and North Korea. To the Americans, the Europeans were able to persist in their high-minded approach only because the US persisted in its own more Darwinian approach. As one writer put it, 'Europe's Kantian order [of "perpetual peace"] depends on the United States using power according to the old Hobbesian rules' of unreliable international principles and potential evildoers that would have to be overcome. ${ }^{29}$

These philosophical differences would not necessarily destroy NATO. 
Indeed, in a world that might still function according to the dictum of the nineteenth-century Prussian soldier Clausewitz that 'war is nothing but the continuation of politics by other means', they might complement each other. However, they could set the stage for quarrels over both the purpose and means of contemplated actions and thus cause alienation to grow and cohesion to weaken, as became manifest in the Iraq crisis in 2003.

On that occasion, NATO found itself seriously divided as it became clear that - due in particular to the threat of a French (but also Russian and Chinese) veto - no UN Security Council Resolution would be passed that authorised the use of military force against Saddam Hussein's Iraq over its alleged non-compliance with previous Security Council calls for the destruction of its presumed weapons of mass destruction. ${ }^{30}$

On the one side stood NATO members France, supported especially by Germany (a non-veto member of the UN Security Council at this time) and Belgium, who argued that NATO should not send even defensive military equipment to protect its NATO partner Turkey against any attack by Iraq. In the opposite camp were countries like the United States, the United Kingdom, Spain, Italy and several of the newer NATO members in Central and Eastern Europe. They felt that military action was now called for and in line with NATO obligations. ${ }^{3 \mathrm{I}}$

In the ensuing invasion of Iraq, NATO was not involved, leaving the alliance deeply split and rendering its role uncertain in any future conflict where perceptions of outside threats and the action needed to counter them might differ.

\section{Notes}

I From his Farewell Address, I796. The United States followed George Washington's precept of not entering into alliances up until I947, when it concluded the Rio Treaty on the Defense of the Western Hemisphere with a number of Latin American countries, followed, in 1949, by the Washington Treaty creating NATO. US participation in the two world wars was not based on any formal alliances.

2 The NATO enlargement in I999 was ratified by the US Senate by a large majority, in spite of concern about its cost. The US State Department in 1997 put the total cost (for all the members) of the first enlargement at between $\$ 27$ and $\$ 35$ billion over I2 years, while other studies pointed to added expenditure of between $\$ 42$ billion and $\$$ Ioo billion. However, a NATO study of early I998 (considered 'definitive'), placed the extra expenditure at less than $\$ 2$ billion. The enlargement project provided for a minimum of communication and 'interoperability' between new NATO members and current ones. It was meant to enable NATO to respond well in time should 
Russian capabilities or intentions ever change. The project also foresaw that the defence of new members be based on reinforcement in crises, rather than on the permanent stationing of combat forces in those countries.

3 Article 5 in the 1949 North Atlantic Treaty states that: 'The Parties agree that an armed attack against one or more of them in Europe or North America shall be considered an attack against them all'. Article I says that: 'The parties undertake ... to settle any international dispute in which they may be involved by peaceful means in such a way that international peace and security and justice are not endangered, and to refrain in their international relations from the threat or use of force in any manner inconsistent with the purposes of the United Nations'. Article 7 recognises the 'primary responsibility of the Security Council for the maintenance of international peace and stability'. (The intervention in Iraq in I99I had been undertaken under the authority of the UN. Similarly, in Bosnia, in I995, NATO action had been authorised by the UN Security Council. In the Kosovo case, UN Security Council intervention was secured only ex post facto, in fact leading to the end of the hostilities following Milosevic's acceptance of the terms of Security Council Resolution I 244.) Finally, concerning enlargement, Article Io states that: 'The Parties may, by unanimous agreement, invite any other European state in a position to further the principles of this Treaty and to contribute to the security of the North Atlantic area to accede to this Treaty'. (The previous enlargements had been Greece and Turkey in I952, the Federal Republic of Germany in 1955 and Spain in I982.)

4 Russia withdrew from co-operation with NATO in March 1999 in reaction to the Kosovo conflict. Co-operation was gradually restored after the end of the conflict.

5 The EAPC included the previously mentioned Partnership for Peace (created in I994) and replaced the Council for North Atlantic Co-operation (established in I99I). By 2002 the EAPC had grown to comprise forty-six countries (nineteen NATO members and twenty-seven others). Moreover, the Dialogue on the Mediterranean, started in I994, was to be enhanced. Finally, the 1997 Madrid Summit decided on a reform of NATO's military structure aiming at greater operational flexibility, fewer headquarters and greater openness to working with outside partners in preparing joint operations.

6 The NATO-Ukraine Charter included regular political consultations on securityrelated issues, defence reform in Ukraine and Ukrainian participation in NATO-led peace support operations in Bosnia and Kosovo. It followed on substantial Ukrainian steps in the defence field, such as the country's destruction of nuclear weapons on its soil following the collapse of the Soviet Union; its accession to the Non-Proliferation Treaty as a non-nuclear state; and its agreement with Russia over the sharing of the Soviet-era Black Sea Fleet. Ukraine army units have participated in numerous exercises with NATO forces since I 994 and contribute troops to the KFOR mission in Kosovo. It provided vital air transport during the military intervention in Afghanistan in 2002.

7 The Madrid Summit Agreement also linked up with the I990 Conventional 
Forces in Europe (CFE) Treaty also known as the Conventional Arms Control Treaty). The latter entered into force in $\mathrm{I} 992$ and has so far been ratified by over thirty countries. The CFE meant a historically unprecedented reduction in conventional forces in Europe. A revised agreement did away with the previous NATO-Warsaw Pact balancing act and instead sought to define 'national' and 'territorial' and 'zonal' 'ceilings', especially in Central Europe. However, the relevance of the CFE to today's Europe was increasingly called into question, for instance in regard to Russia, especially after the creation, in May 2002, of the NATO-Russia Council. Russia's military strength and readiness in the conventional field never came close to the threat limits established in the CFE, other than during fighting in Chechnya.

8 NATO's conditions included a Serbian military withdrawal from Kosovo; the return of all refugees; a well-armed international military presence to protect them; and a Kosovo autonomy within Serbian sovereignty.

9 The Rambouillet Agreement of February I995 - signed by the ethnic Albanian side but not by the Federal Republic of Yugoslavia - foresaw that Kosovo would remain a Serbian province, but with extensive autonomy for its Albanian majority, to be supervised by NATO peacekeeping forces. After the conflict it became a dead letter for many ethnic Albanians, who could not conceive of having their province form part of Yugoslavia after the atrocities committed against them.

Io Guéhenno (I998-9, p. Io) speaks of the 'ascendance of a humanitarian view of foreign policy', in which 'upholding moral standards could become a strategic goal'. However, he also sees, for example, the Dayton Agreements of I995 as revealing

the limited depth of the West's commitment to such standards. Although moved to act by moral pressure as much as by traditional strategic considerations, the solution found at Dayton was of a traditional nature. Rather than deploy sufficient forces to uphold international standards of behaviour, the US and its European allies created a balance of forces on the ground between the Muslim-Croat federation and the Serbs. The horrors of the Muslim-Croat war were conveniently forgotten and the Serbs contained, but Bosnia's de facto division through ethnic cleansing was accepted, and no side could claim the moral high ground. The war was, at least temporarily, ended; it is, however, unclear whether peace was made.

I I The move toward effective universal jurisdiction took a major step forward with the coming into existence of an International Criminal Court (ICC) in April 2002. The ICC has the right to go after what it perceives as war criminals anywhere in the world, even in countries not party to it. Supporters argue that this is vitally needed to apprehend the likes of Milosevic (who is now before the International Criminal Tribunal for the former Yugoslavia in The Hague). Opponents, however, see in the ICC a court lacking meaningful political oversight and potentially dominated by unscrupulous regimes. They consider the international political arena as, essentially, not appropriate for legal action. The United States, under President George W. Bush in 2002 nulli- 
fied the Clinton administration's signature of the ICC Treaty and announced that it would not send it for ratification to the Senate. It even threatened to withdraw from UN peacekeeping operations such as in Bosnia, unless the UN Security Council guaranteed that no US soldier would be brought before the ICC over alleged war crimes. A compromise was eventually reached for a suspension of the threatened action. A dispute with the EU over the issue was at least temporarily resolved in 2002, as the latter permitted the US to conclude deals with individual EU (and candidate) states ensuring immunity from ICC prosecution for US soldiers and government officials. EU countries strongly supportive of the ICC considered the compromise a defeat in the quest for a common EU foreign and security policy.

I 2 Shawcross (2000) points to what he sees as a considerable inconsistency on the part of the world community - as represented by the UN and its Security Council - in crisis or conflict intervention since the end of the Cold War. Why Cambodia, Bosnia, Kosovo and East Timor, and not Rwanda, the Congo or Chechnya? The determinants, he concludes in resignation, are practical politics and money, and not moral outrage. He also argues that the intervention of peacekeepers can sometimes prolong conflicts, such as when they prevented either the government or the UNITA rebels from winning the civil war in Angola in the early I990s.

I3 Russia had considerable problems in reducing the size of its military. Entire branches of service were foreseen to disappear, and along with them the careers of thousands of officers, with unknown consequences for social stability and employment. Furthermore, scores of cities in the Urals, the Caucasus and elsewhere, built purely for military purposes during the Soviet era, would have to convert to civilian production or simply be closed down for lack of a civilian purpose. The cost of all this was uncertain, but without economic development the process would be even more difficult.

I4 Ukraine - a resource-rich country, bigger than France - was considered of great importance to European stability. Located between Russia and SouthEastern Europe, it served as a counterweight to the former at regional level. Western Europe and NATO would have a natural interest in seeing a strong and stable Ukraine, while NATO membership was not for the near future. By contrast, the undemocratic government of Belarus and its international isolation was considered to preclude any early membership in NATO.

I 5 The selection of the countries with which NATO would start membership negotiations was to follow criteria established under a Membership Action Plan (MAP), covering not only military but also economic, political and legal aspects and building on the I994 Partnership for Peace programme. In the end, however, the decision on membership would be taken as much on political grounds as on the basis of technical criteria.

I6 Address by President George W. Bush to faculty and students of Warsaw University, Warsaw, Poland, I5 June 200I (www.whitehouse.gov/news/ releases/200I/06/200I06I 5-I). 
I7 The Ballistic Missile Defence is to consist of five sub-systems: (I) a satelliteborne early warning system; (2) an additional earthbound early warning system, permitting more precise predictions of missile direction and the identification of decoys; (3) an equally land-based 'X-band' radar system for the same purposes; (4) launch of destroying missiles and destruction of targets; and (5) success evaluation and, in the event of failure, launch of additional destroying missiles. Construction of a first site in Alaska would start in 2004 and lead, in the first instance, to the readying of around twenty destroying missiles by 2006. The installation is meant to counter long-range ballistic missiles and will be supplemented gradually by systems installed on warships to shoot down short and medium-range enemy missiles.

I 8 The I972 ABM Treaty stipulated that the United States and the Soviet Union could have only two missile defence sites of not more than one hundred rockets; one around the capital and one around an attack missile centre. The treaty, once ratified by both countries, underwent several mutually agreed modifications. Building on the Mutual Assured Destruction (MAD) doctrine, it was an important building block for the subsequent Strategic Arms Limitation Talks (SALT), especially SALT I, and for the later START II agreements. The United States in $200 \mathrm{I}$ had 7,000 strategic nuclear weapons, a number meant to fall to around 3,000 under START II. In I997, Washington and Moscow agreed in principle that a forthcoming treaty should lower the number of missiles for each side to around 2,000. This goal came closer with the signing, in 2002, of the Treaty of Moscow, signifying cuts to this level.

It could be argued, in the case of 'MAD', that it has kept world peace for over fifty years. However, its weakness is that it assumes rational behaviour by all sides concerned. However, what if there is a leader of a 'rogue' nation, recently equipped with nuclear weapons, who is not rational but irrational, perhaps suicidal, somewhat like Hitler or Milosevic? Even in the Cuban missile crisis of 1962, the US and the Soviet Union behaved rationally only in the end, and then almost by chance. A Ballistic Missile Defence could lift the threshold for the application of the MAD doctrine, by permitting a country which is being attacked to shoot down a missile and thus avoid instantaneous massive retaliation, at least until after all the facts of the incident have been established.

I9 Some experts on nuclear deterrence, such as Allison and Zelikov (I999, pp. 397-40I) argue that the risk of a nuclear exchange originating in Russia is not yet over. They in particular point to (I) 'Russia's deteriorating command and control systems, both technical and human, that increase risks of unauthorised or accidental launch of nuclear weapons'; (2) 'the decline of Russia's conventional military capabilities [which] has increased reliance on nuclear weapons [in a crisis]'; and [3] 'loose nukes', that is, Russian nuclear weapons that are stolen, sold to terrorists or rogue states.

20 However, in 2003 Russia proposed to the United States the conclusion of a 
new Ballistic Missile Defence Treaty, by which Russia would benefit from the US BMD system. If this becomes reality, NATO's European partners would be hard pressed to join, too.

2I The Treaty of Moscow leaves either country free to rebuild its forces as from one year after the treaty's expiration if it is not extended or amended.

22 The NATO-Russia Council effectively replaced the NATO-Russia Permanent Joint Council, which had been largely ineffectual, not least during the period when Russia-NATO relations cooled during the Kosovo conflict.

23 Russian efforts to exercise greater influence over its southern flank became manifest in the spring of 2002, when it announced the creation of a Collective Security Treaty Organisation also including the Community of Independent States partners Armenia, Belarus, Kazhakstan and Tajikistan.

24 The enlargement, to be formally declared at a NATO summit in May 2004, was expected to pave the way for various other countries such as Albania, the 'former Yugoslav Republic of Macedonia' and Croatia, provided they made further progress on democratic consolidation and defence readiness.

25 As NATO undergoes enlargement in coming years, the relevance of its fortysix-member-state Euro-Atlantic Partnership Council (EAPC) and its Partnership for Peace (PfP), which also includes certain countries in South-East Europe and Central Asia, is being called into question. While the EAPC may well disappear, the PfP may remain as a means for projecting NATO power into Afghanistan and other countries in the region.

26 Reflecting the international community's growing fear over the proliferation of weapons of mass destruction, over ninety countries - including the United States and Russia - in 2002 signed the International Code of Conduct against Ballistic Missile Proliferation. The Code is not, however, of a binding nature; nor does it foresee any control mechanism, sanctions or ban on exports of such weapons or their components. Among the non-signatories are India, Pakistan, China, North Korea, Syria and Israel.

27 Speech by President George W. Bush, West Point, New York, I June 2002; quoted in The National Security Strategy of the United States of America, September 2002 (The White House). The National Security Strategy raises many other objectives, such as that to 'build a balance of power [in the world] that favours freedom ... [and] bring the hope of democracy, development, free markets and free trade to every corner of the world'.

28 Naumann (2002, p I95) recommends a strategy for conflict prevention and peace maintenance as having two elements: 'Conflict pre-emption seeks to resolve conflicts by political means and prevent new causes of conflict from arising through assistance. Thereby the soil in which terror and violence thrive will be taken away. Conflict prevention seeks to make attacks purposeless through the greatest possible protection of states and societies, and to show potential aggressors through intervention far away from their own regions that they run the risk of losing their capacity for attack as well as that of being apprehended. It is the idea of the carrot and the stick, of helping and 
punishing ... The time may have come to develop a comprehensive political strategy, in which the military element plays an irreplaceable - but not the only and often not even the dominant - role.' (Translated from the German original.)

$29 \operatorname{Kagan}(2002$, p. I).

30 UN Security Council Resolution I44I of 8 November 2002 threatened Iraq with 'serious consequences' in the event of any further 'material breach' of Security Council Resolution 678 of April r99I (adopted in the wake of the I99I allied military intervention in Iraq and as a condition for an armistice) and more than a dozen UN Resolutions adopted in the intervening years. The United States, the United Kingdom, Australia and other countries considered that the words in Resolution 678 authorising the use of 'all necessary means' in the event of Iraqi non-compliance with an earlier Resolution 660 of I990 (following Iraq's occupation of Kuwait) should apply also in 2002, whereas the countries opposed to military intervention argued that 'serious consequences' did not authorise such action in the absence of another UN Security Council Resolution including words such as 'all necessary means'.

3I Article 4 of the North Atlantic Treaty states: 'The Parties will consult together whenever, in the opinion of any of them, the territorial integrity, political independence or security of any of the Parties is threatened'. 